\title{
Concentrations of faecal glucocorticoid metabolites in South African Mutton Merino sheep fed various sources of roughage
}

\author{
H.A. O'Neill' ${ }^{1 /}$, O.B. Einkamerer', B.T. Elago' \& A. Ganswindt ${ }^{2}$ \\ ${ }^{1}$ Department of Animal, Wildlife and Grassland Sciences, University of the Free State, Bloemfontein, South Africa \\ ${ }^{2}$ Mammal Research Institute, Department of Zoology and Entomology, Faculty of Natural and Agricultural Sciences, \\ University of Pretoria, Hatfield, South Africa
}

(Submitted 4 June 2019, Accepted 6 May 2020, Published online 20 August 2020)

\begin{abstract}
The objective of this study was to determine whether various sources of roughage in nutritionally balanced feedlot diets would evoke a stress response in sheep. A nutritional stress response test was performed on 20 ewes, randomly divided into four treatment groups with 5 ewes per group. Ewes were kept individually in metabolic crates for thirty days. Rations were balanced nutritionally, and various sources of roughage were included; T1: alfalfa hay, T2: maize stover, T3: soya hulls; and T4: Eragrostis tef. Faeces was removed manually from the caudal rectum of each ewe at $05 \mathrm{~h} 00$ and $19 \mathrm{~h} 00$. Samples were frozen at $-20^{\circ} \mathrm{C}$ until analyses. A total of 520 faecal samples were analysed to determine the concentrations of faecal glucocorticoid metabolites (fGCM) by enzyme immunoassay (EIA). These concentrations were expressed as mass $/ g$ dry weight (ng/g DW). Baseline values were determined, and those greater than the mean plus 2 standard deviations were removed. Baseline values were compared between the groups with one-way ANOVA analysis. The average concentrations of fGCM were $178.77 \pm 21.7$ in the morning and $183.2 \pm 14.4$ in the evening. Sheep fed T4 had significantly higher fGCM concentrations in both morning (302.0 \pm 86.1 $\mathrm{ng} / \mathrm{g}$ DW) and evening $(237.0 \pm 48.1 \mathrm{ng} / \mathrm{g} \mathrm{DW})$ compared with the other treatment groups. Thus, fGCM concentrations in sheep were related to the source of roughage, and Eragrostis tef caused a stress response.
\end{abstract}

Keywords: animal welfare, cortisol, dietary fibre, selective grazer, stress response

"Corresponding author: oneillha@ufs.ac.za

\section{Introduction}

Systems of mutton production in South Africa include extensive and intensive practices. Pasture conditions in extensive conditions often expose sheep to harsh habitats, hazardous environmental and climatic conditions and hot temperatures (Abecia et al., 2006; Corson et al., 2007). As a result of these challenging environmental conditions, producers are turning towards intensive production, which is characterized by a closed system of feeding pens or feedlots. This practice requires large amounts of labour and capital input relative to land area to keep the animals healthy while production performance is enhanced (Morand-Fehr et al., 2007). The stocking density is high, and farmers use cultivated pastures.

Roughages are included in a nutritionally balanced diet through proper feed formulation. The fibre quality of a roughage influences the digestibility and feed conversion ratio (FCR) of a diet. Alfalfa is a highquality fibre source, which makes it an ideal nutritional feed source for sheep (Doran et al., 2007). Maize stover is the by-product that remains after harvesting maize. It is often used as livestock feed during the dry season. Its quality may differ owing to variations among maize genotypes (Ertiro et al., 2013). But its high fibre and low nitrogen content make maize stover less nutritious, unless animals are supplemented with nitrogen (Manyuchi, 1994). Soybean hulls are a by-product of soybean seeds after oil extraction. Soybean meal guarantees maximum protein of $44 \%$ to $48 \%$ and $0.5 \%$ fat (McEllhiney, 1995) after oil extraction. For this reason, soybean hulls are a good source of energy in diets that are more forage based. Teff (Eragrostis tef (Zuccagni trotter)) is known for its quality, high yield and ability to grow faster than other crops (Zeid et al., 
2011). It is used mostly as forage production in areas that are dry and have short rain seasons (Kaholongo, 2016). Today, teff is grown mainly for hay, particularly in South Africa, Australia and the USA (Miller, 2010).

Intensive production systems prevent sheep from grazing naturally. Sheep are naturally selective grazers and some breeds are more selective than others. For example, Dorper sheep are less selective than Merino-type breeds (Brand, 2000). Feedlot production restricts the normal selection behaviour of sheep, which are fed formulated diets. Restricting normal behaviour in sheep may evoke a stress response.

Stress may be defined as 'the inability of an animal to cope with its environment'. This phenomenon is revealed by failure to achieve genetic potential for growth rate, milk yield, disease resistance and fertility (Bayazit, 2009). Stress may be described in biological terms as a response that is elicited when an individual is under threat (Engelmann et al., 2004). An individual will attempt to counter stress through behavioural responses or unconscious adaptations via physiological and biochemical mechanisms (Bashaw et al., 2016). However, there are individual differences in behaviour and in the ways in which livestock species respond to stressful situations. It is important to understand not only herd differences, but also individual animal ones (O'Neill, 2019). Stress experienced by sheep cannot be avoided and forms part of normal management practices (Dwyer, 2009). The hypothalamic pituitary adrenal response is an evolutionary mechanism that enables an individual to return to homoeostasis. Whereas short-term stressors and the physiological consequences may be desirable in some cases, chronic stress has a negative impact on production efficiency, that is, the suppression of normal oestrus behaviour and reduced ewe fertility (Marai et al., 2007).

Researchers have attempted to measure stress and stress responses in animals for many years. Three main methods are used to measure stress in sheep: i) observing overall body condition, ii) analysing physiological responses such as cortisol concentration, and iii) observing general behavioural changes (Weary et al., 2006; Gougoulis et al., 2010; Kruger et al., 2016). Sheep are known to be stoical creatures and do not always reveal discomfort or distress that is experienced physically or behaviourally. Close observation is important in identifying stress in sheep.

Glucocorticoids (GC) are a class of steroid hormones that bind to the glucocorticoid receptor, which is present in almost every vertebrate animal cell (Royo et al., 2004). The GC are part of the feedback mechanism in the immune system that inhibits access of leukocytes to a site of inflammation (Möstl \& Palme, 2002; Von der Ohe \& Servheen, 2002). Glucocorticoids have diverse effects, including potentially harmful side effects (Pihl \& Hau, 2003). Stress increases the GC concentrations in the blood of mammals, making blood an obvious matrix to evaluate stress responsiveness (Tuli et al., 1995). Circadian cycles control adrenocortical responses after a stressful event (Przekop et al., 1985; De et al., 2017). The effect of the circadian rhythm on cortisol patterns should be considered carefully in stress assessments and use of a single sample of cortisol per day should be avoided (De Jong et al., 2000). It is preferable to measure endogenous cortisol levels over 24 hours (Monfort et al., 1993).

Unfortunately, capture and restraint of the animal for blood sampling causes it stress. Non-invasive methods to determine the concentration of GC or its metabolites are more desirable (Kruger et al., 2016; Nemeth et al., 2016; Palme, 2019). Samples that can be obtained using alternative non-invasive techniques include faecal, salivary, milk and hair (Siswanto et al., 2008). However, there are many challenges in most sampling procedures. Saliva collection means handling an animal, and milk sampling is limited to lactating animals (Möstl \& Palme, 2002). Faecal and salivary samples present an opportunity for non-invasive measurement of corticosteroids and immunoglobulin A (Pihl \& Hau, 2003; Touma \& Palme, 2005). Faecal glucocorticoid metabolite concentrations reflect glucocorticoid production in an animal's system after a certain time. The lag time for fGCM concentration in ruminants is $13 \pm 4$ hours. Faecal and salivary samples are less affected by short-term fluctuations of hormone secretion than blood samples (Touma \& Palme, 2005).

Foraging involves interaction between the characteristics of the animals and those of the food in the environment (Prache et al., 1998). The purpose of this study was to assess whether various sources of roughage that were fed to animals in an intensive controlled system would evoke stress responses in sheep.

\section{Methods and Materials}

This study was carried out in accordance with the guidelines of the Ethics Committee (Reference UFSAED2017/0031) of the University of Free State, in autumn 2018 at Paradys Experimental Farm $\left(29^{\circ} 13^{\prime}\right.$ $\left.19.78^{\prime \prime} \mathrm{S}, 26^{\circ} 12^{\prime} 26.48^{\prime \prime} \mathrm{E}\right)$, which is situated $20 \mathrm{~km}$ from Bloemfontein, Free State, South Africa. A total of 20 South African Mutton Merino (SAMM) ewes, seven months old, and weighing $28 \mathrm{~kg}$ on average were randomly allocated to one of four treatment groups. These groups consisted of T1 $(n=5)$ : alfalfa hay, T2 $(n$ $=5)$ : maize stover, T3 $(n=5)$ : soya hulls, and T4 $(n=5)$ : Eragrostis tef. Rations were balanced nutritionally, and various fibre sources were used (Table 1).

Sheep were kept individually in metabolic crates for thirty days after an adaptation period of eight days. Diets were fed ad libitum for the experimental period. At the onset and end of the study, all animals 
were fasted overnight (minimum of 12 hours) and individual empty stomach bodyweight was recorded the next morning. Animals were provided with feed twice daily at $07 \mathrm{~h} 00$ and at $17 \mathrm{~h} 00$ during the study. Feed troughs were designed/ to determine individual quantities of ingested feed and to minimize feed wastage.

Table 1 Physical and chemical composition of four diets including different sources of fibre

\begin{tabular}{lrrrr}
\hline \multirow{2}{*}{ Raw materials (\% inclusion) } & \multicolumn{3}{c}{ Dietary treatment } \\
\cline { 2 - 5 } & \multicolumn{1}{c}{ T1 } & \multicolumn{1}{c}{ T2 } & T4 \\
\hline Maize meal & 55.00 & 55.00 & 55.00 & 55.00 \\
Lucerne & 34.97 & 0.00 & 0.00 & 0.00 \\
Maize stover & 0.00 & 19.53 & 0.00 & 0.00 \\
Eragrostis & 0.00 & 0.00 & 0.00 & 21.63 \\
Citrus pulp & 6.89 & 20.05 & 17.70 & 17.94 \\
Soya oil cake & 0.03 & 0.29 & 0.00 & 0.24 \\
Soya hulls & 0.00 & 0.00 & 22.85 & 0.00 \\
Urea & 0.66 & 2.07 & 1.43 & 1.91 \\
Limestone & 0.25 & 0.72 & 0.67 & 0.85 \\
Ammonium chloride & 0.75 & 0.75 & 0.75 & 0.75 \\
Mono-calcium phosphate & 0.70 & 0.85 & 0.85 & 0.92 \\
Salt & 0.50 & 0.50 & 0.50 & 0.50 \\
Premix & 0.25 & 0.25 & 0.25 & 0.25 \\
Nutrient composition (\% DM) & & & & \\
Crude protein & 14.50 & 14.50 & 14.50 & 14.50 \\
Metabolizable energy (MJ ME/kg DM) & 11.28 & 11.60 & 12.19 & 11.25 \\
Neutral detergent fibre & 22.83 & 22.83 & 22.83 & 22.83 \\
Acid detergent fibre & 15.48 & 13.85 & 15.35 & 12.06 \\
Ether extract & 3.35 & 3.35 & 3.35 & 3.35 \\
Calcium & 0.83 & 0.83 & 0.83 & 0.83 \\
Phosphorus & 0.40 & 0.40 & 0.40 & 0.40 \\
& & & & \\
\hline T1: alfalfa hay, T2: maize stovery T3: soya & & & &
\end{tabular}

T1: alfalfa hay, T2: maize stover, T3: soya hulls, T4: Eragrostis tef

Approximately $20 \mathrm{~g}$ faeces were removed manually twice a day A total of 520 faecal samples were collected for 14 days and then again at day 30 of the trial. Samples were collected at the same times each day at 05h00 - 06:00 and 19h00 - 20h00. Each faecal sample was placed in a sterile glass container with a screw lid. Samples were put on ice in a cooler bag and frozen within 30 minutes of collection. Samples were kept in a freezer at $-20^{\circ} \mathrm{C}$ until analyses.

Laboratory analyses were conducted at the Endocrine Research Laboratory, University of Pretoria (Ganswindt et al., 2002). Faecal glucocorticoid metabolite concentrations were measured with an enzyme immunoassay (EIA). 11-oxoetiocholanolone was used as a group-specific enzyme detecting immunoassay by measuring 11,17-dioxoandrostane (see Palme \& Möstl, 1997).

Frozen samples were lyophilized, pulverized and then sieved through a wire-mesh strainer to remove undigested material. Enzyme immune assays were performed on microtiter plates according to Ganswindt et al. (2002). Fifty $\mu$ l aliquots of standards (range $1.9-500 \mathrm{pg}$ for EA), quality controls and diluted faecal extract were pipetted in duplicate into the microtiter plate wells. Then $50 \mu \ell$ of EA label was added and the plates were incubated overnight at $4{ }^{\circ} \mathrm{C}$. After incubation, the plates were washed four times and $150 \mu \ell(20 \mathrm{ng})$ streptavidin-peroxidase was added to each well. After incubation in the dark for 30 minutes while shaking, 
plates were washed again before $150 \mu \ell$ peroxidase substrate solution was added. Plates were then incubated for $30-60 \mathrm{~min}$ while shaking. The reaction was terminated by adding $50 \mu \mathrm{l}$ of 4 normal sulphuric acid and optical density was measured at $450 \mathrm{~nm}$. To adjust for variations in water content, faecal hormone concentrations were expressed as mass $/ \mathrm{g}$ DW. The sensitivity of the EIA was $1.2 \mathrm{ng} / \mathrm{g}$ faecal DW. The intraassay coefficient of variance, which was determined by repeated measurement of high- and low-value quality controls, ranged from $3.83 \%$ to $4.09 \%$ and the inter-assay coefficient of variance ranged from $7.72 \%$ to $9.59 \%$.

Baseline values of fGCM concentrations were determined for each group using an iterative process in which all values greater than the mean plus 2 standard deviations (SD) were removed (Brown et al., 1999). Averages were recalculated and the elimination process was repeated until there were no values greater than the mean plus $2 \mathrm{SD}$.

For all groups, fGCM data were pooled and differences in hormone concentration levels were examined with one-way ANOVA, followed by Tukey test post-hoc analysis. The baseline values from the fGCM concentration levels of individual sheep were then compared among all groups. The initial rise, peak and fall in fGCM concentration after the introduction of the treatment feed were determined and analysed using descriptive statistics. Means and variances of all groups were compared using ANOVA analysis of $R$ statistical package and Kruskal-Wallis ANOVA on ranks. The package was also used to detect significant differences between the groups according to treatments. For all statistical analyses, significance was assumed when $P<0.05$.

\section{Results and Discussion}

This study formed part of a production trial. Average daily weight gain (ADG) and average daily feed intake (ADI) were recorded and used to calculate FCR. There were no significant differences in FCR between groups. The experimental diets were comparable and ADI and ADG were not significantly different among groups in this study.

Table 2 Average ( $\pm S E$ ), maximum and minimum faecal glucocorticoid metabolites ( $\mathrm{ng} / \mathrm{g} \mathrm{DW}$ ) in the morning and evening for South African Mutton Merino ewes fed various sources of roughage

\begin{tabular}{|c|c|c|c|c|c|c|}
\hline \multicolumn{2}{|c|}{ Measurement } & \multirow{2}{*}{$\begin{array}{c}\mathrm{T} 1 \\
113.10 \pm 25.91^{\mathrm{a}}\end{array}$} & \multirow{2}{*}{$\begin{array}{c}\mathrm{T} 2 \\
153.69 \pm 42.30^{\mathrm{a}}\end{array}$} & \multirow{2}{*}{$\begin{array}{c}\text { T3 } \\
146.28 \pm 35.46^{\mathrm{a}}\end{array}$} & \multirow{2}{*}{$\frac{\mathrm{T} 4}{301.99 \pm 86.05^{\mathrm{b}}}$} & \multirow{2}{*}{$\begin{array}{c}\text { Average } \\
178.77 \pm 21.69\end{array}$} \\
\hline AM & Average & & & & & \\
\hline & Minimum & 21.43 & 10.85 & 16.04 & 18.98 & $16.83 \pm 1.17$ \\
\hline & Maximum & 223.07 & 330.28 & 296.81 & 796.62 & $411.70 \pm 67.26$ \\
\hline \multirow[t]{3}{*}{ PM } & Average & $165.73 \pm 41.86^{\mathrm{a}}$ & $169.45 \pm 45.86^{\mathrm{a}}$ & $162.30 \pm 34.96^{\mathrm{a}}$ & $236.98 \pm 48.10^{b}$ & $183.2 \pm 14.38$ \\
\hline & Minimum & 15.09 & 14.76 & 22.89 & 48.46 & $25.30 \pm 4.10$ \\
\hline & Maximum & 351.47 & 385.89 & 311.95 & 442.94 & $373.07 \pm 14.34$ \\
\hline
\end{tabular}

T1: alfalfa hay, T2: maize stover, T3: soya hulls, T4: Eragrostis tef

a,b Within a row values with a common superscript do not differ at $P=0.05$

Average morning fGCM concentration ranged from $113.10 \pm 25.91 \mathrm{ng} / \mathrm{g}$ DW (T1) to $301.99 \pm 86.05$ $\mathrm{ng} / \mathrm{g}$ DW (T4). Average evening fGCM concentration ranged from $162.30 \pm 34.96 \mathrm{ng} / \mathrm{g}$ DW (T3) to $236.98 \pm$ $4810 \mathrm{ng} / \mathrm{g}$ DW (T4). Pooled average morning fGCM concentration was $178.77 \pm 21.69 \mathrm{ng} / \mathrm{g}$ DW and evening fGCM concentration was $183.2 \pm 14.38 \mathrm{ng} / \mathrm{g} \mathrm{DW}$. Overall, there were no significant differences in fGCM concentrations of samples collected in the mornings compared with those collected in the evening (Table 2). This contrasts with the patterns observed in cattle (Touma \& Palme, 2005) and buffaloes (Ganswindt et al., 2012). Ganswindt et al. (2012) demonstrated that glucocorticoids have circadian rhythm and diurnal differences, which classifies ruminants as diurnal animals with activity peaking during the day. The lag time for fGCM was about 13 hours. Thus the time of sampling is a reflection of the situation about 13 hours earlier (Touma \& Palme, 2005). T4 was an exception, with higher fGCM levels on average in the mornings (301.99 $\pm 86.05 \mathrm{ng} / \mathrm{g}$ ) compared with the evenings $(236.98 \pm 48.10 \mathrm{ng} / \mathrm{g})$, but the reason is not clear. High variations in data indicate a possible sampling error and may be a result of small sampling groups.

There were no significant differences for fGCM between T1, T2, and T3 for mornings and evenings. Faecal glucocorticoid metabolite concentration for T4 was significantly higher $(P<0.05)$ in the morning and the evening compared with T1, T2, and T3. Preventing animals from grazing selectively and feeding a 
roughage source that consisted mainly of teff evoked a stress response in sheep. In comparison, the voluntary intake of a teff only diet was lower. It was suggested that an optimum level of condensed tannin sources must be fed to sheep to improve feed intake and growth performance (Kaitho et al., 1997). Santhi et al. (2017) suggested that parasitized animals have the ability to self-medicate because ingested plant phenolics, mainly tannins, reduce strongyle nematode infections in mammalian herbivores.

\section{Conclusion}

This study confirmed that fGCM measurement offered a practical alternative for investigators to monitor adrenocortical activity in sheep non-invasively. Eragrostis tef induced physiological stress in sheep that were not able to graze naturally. Other roughage sources must be fed to feedlot animals in conjunction with teff to ensure voluntary food intake and production efficiency. This study opened an avenue for further research on fibre preferences and animal health. In future, more research must be done on the natural selection of roughage sources and its provision in a feedlot diet because teff evoked a stress response. The ability to measure fGCM in SAMM sheep reliably with a non-invasive method would give a firm basis for further examination of physiological responses to stressful circumstances in commercially reared sheep.

\section{Acknowledgements}

The support and financial aid from Dr O.B. Einkamerer is appreciated.

\section{Authors' Contributions}

Conception, design and drafting of paper AON; data collection and analyses BTE; and critical review OBE

\section{Conflict of Interest Declaration}

There are no conflicts of interest.

\section{References}

Abecia, J.A., Sosa, C., Forcada, F. \& Meikle, A., 2006. The effect of undernutrition on the establishment of pregnancy in the ewe. Reprod. Nutr. Dev. 46(4), 367-378. DOI: 10.1051/rnd:2006018

Bashaw, M.J., Sicks, F., Palme, R., Schwarzenberger, F., Tordiffe, A.S. \& Ganswindt, A., 2016. Non-invasive assessment of adrenocortical activity as a measure of stress in giraffe (Giraffa camelopardalis). BMC Vet, Res. 12(1), 235. DOI org/10.1186/s12917-016-0864-8

Bayazit, V., 2009. Evaluation of cortisol and stress in captive animals. Aust. J. Basic. Appl. Sci. 3, $1022-31$.

Brand, T.S., 2000. Grazing behaviour and diet selection by Dorper sheep. Small Ruminant Res. 36(2), 147-158. DOI org/10.1016/S0921-4488(99)00158-3

Corson, M.S., Rotz, C.A. \& Skinner, R.H., 2007. Evaluating warm-season grass production in temperate-region pastures: A simulation approach. Agric. Syst. 93(1-3), 252-268. DOI org/10.1016/j.agsy.2006.06.001

De Jong, I.C., Prelle, I.T., Van de Burgwal, J.A., Lambooij, E., Korte, S.M., Blokhuis, H.J. \& Koolhaas, J.M., 2000. Effects of environmental enrichment on behavioral responses to novelty, learning, and memory, and the circadian rhythm in cortisol in growing pigs. Physiol. Behav. 68(4), 571-578. DOI org/10.1016/S0031-9384(99)00212-7

De, K., Kumar, D., Saxena, V.K. \& Naqvi, S.M.K., 2017. Study of circadian rhythmicity of physiological response and skin temperature of sheep during summer and winter in semi-arid tropical environment. Physiol. Behav. 169, 16-21. DOI org/10.1016/j.physbeh.2016.11.010

Doran, M.P., Laca, E.A. \& Sainz, R.D., 2007. Total tract and rumen digestibility of mulberry foliage (Morus alba), alfalfa hay and oat hay in sheep. Anim. Feed. Sci. Tech. 138(3-4), $239-253$. https://doi.org/10.1016/j.anifeedsci.2006.11.016

Dwyer, C.M., 2009. Welfare of sheep: Providing for welfare in an extensive environment. Small, Rumin. Res. 86(1-3), 1421. DOI org/10.1016/j.smallrumres.2009.09.010

Engelmann, M., Landgraf, R. \& Wotjak, C.T., 2004. The hypothalamic-neurohypophysial system regulates the hypothalamic-pituitary-adrenal axis under stress: An old concept revisited. Front. Neuroendocrinol. 25(3-4), 132149. DOI org/10.1016/j.yfrne.2004.09.001

Ertiro, B.T., Twumasi-Afriyie, S., Blümmel, M., Friesen, D., Negera, D., Worku, M., Abakemal, D. \& Kitenge, K., 2013. Genetic variability of maize stover quality and the potential for genetic improvement of fodder value. Field Crops Res. 153, 79-85. DOI org/10.1016/j.fcr.2012.12.019

Ganswindt, A., Heistermann, M., Borragan, S. \& Hodges, J.K., 2002. Assessment of testicular endocrine function in captive African elephants by measurement of urinary and faecal androgens. Zoo Biology 21(1), 27-36. DOI org/10.1002/zoo.10034

Ganswindt, A., Brown, J.L., Freeman, E.W., Kouba, A.J., Penfold, L.M., Santymire, R.M., Vick, M.M., Wielebnowski, N., Willis, E.L. \& Milnes, M.R., 2012. International Society for Wildlife Endocrinology. Biol. Lett. 8, 695-697. DOI org/10.1098/rsbl.2011.1181

Gougoulis, D.A., Kyriazakis, I. \& Fthenakis, G.C., 2010. Diagnostic significance of behaviour changes of sheep: A selected review. Small Ruminant Res. 92(1-3), 52-56. DOI org/10.1016/j.smallrumres.2010.04.018

Kaholongo, L.T., 2016. Screening of indigenous forage legumes as potential fodder crops and protein source for livestock in central Namibia. Doctoral dissertation, University of Namibia. 
Kaitho, R.J., Umunna, N.N., Nsahlai, I.V., Tamminga, S. \& Van Bruchem, J., 1997. Utilization of browse supplements with varying tannin levels by Ethiopian Menz sheep: 1. Intake, digestibility and live weight changes. Agrofor. Syst. 39(2), 45-159.

Kruger, L.P., Nedambale, T.L., Scholtz, M.M. \& Webb, E.C., 2016. The effect of environmental factors and husbandry practices on stress in goats. Small Ruminant Res. 141, 1-4. DOI org/10.1016/j.smallrumres.2016.06.004

Manyuchi, B., 1994. High quality forages as supplements to low quality forages for ruminants. Effects on intake, digestibility and rumen digesta dynamics. Doctoral dissertation, University of Aberdeen.

Marai, I.F.M., El-Darawany, A.A., Fadiel, A. \& Abdel-Hafez, M.A.M., 2007. Physiological traits as affected by heat stress in sheep - a review. Small Ruminant Res. 71(1-3), 1-12. DOI org/10.1016/j.smallrumres.2006.10.003

McEllhiney, R., 1995. Quality control in feed manufacturing. American Soybean Association, Brussels. Pp.1-20.

Miller, D.R., 2010. Teff grass crop overview and forage production guide (second edition). Cal/West Seed Company. Woodland, CA.

Monfort, S.L., Brown, J.L. \& Wildt, D.E., 1993. Episodic and seasonal rhythms of cortisol secretion in male Elds deer (Cervus eldi thamin). J. Endocrinol. 138(1), 41-49. DOI org/10.1677/joe.0.1380041

Morand-Fehr, P., Fedele, V., Decandia, M. \& Le Frileux, Y., 2007. Influence of farming and feeding systems on composition and quality of goat and sheep milk. Small Rumin. Res. 68(1-2), 20-34. DOI org/10.1016/j.smallrumres.2006.09.019

Möstl, E. \& Palme, R., 2002. Hormones as indicators of stress. Domest. Anim. Endocrinol. 23(1-2), 67-74. DOI org/10.1016/S0739-7240(02)00146-7

Nemeth, M., Pschernig, E., Wallner, B. \& Millesi, E., 2016. Non-invasive cortisol measurements as indicators of physiological stress responses in guinea pigs. PeerJ. 4, e1590. DOI org/10.7717/peerj.1590

O'Neill, H.A., 2019. A review on the involvement of catecholamines in animal behaviour. S. Afr. J. Anim. Sci. 49(1), 1-8. http://dx.doi.org/10.4314/sajas.v49i1.1

Palme, R. \& Möstl, E. 1997. Measurement of cortisol metabolites in faeces of sheep as a parameter of cortisol concentration in blood. Mamm. Biol. 62 (Suppl. II), 192-197.

Palme, R., 2019. Non-invasive measurement of glucocorticoids: Advances and problems. Physiol. Behav. $199229-243$. DOI org/10.1016/j.physbeh.2018.11.021

Pihl, L. \& Hau, J., 2003. Faecal corticosterone and immunoglobulin A in young adult rats. Lab. Anim. 37(2), 166-171. DOI org/10.1258/00236770360563822

Prache, S., Gordon, I.J. \& Rook, A.J., 1998. Foraging behaviour and diet selection in domestic herbivores. Ann. Zootech. 47, 335-345.

Przekop, F., Stupnicka, E., Wolińska-Witort, E., Mateusiak, K., Sadowski, B. \& Domański, E., 1985. Changes in circadian rhythm and suppression of the plasma cortisol level after prolonged stress in sheep. Eur. J. Endocrinol. 110(4), 540-545.

Royo, F., Bjork, N., Carlsson, H.E., Mayo, S. \& Hau, J., 2004. Impact of chronic catheterization and automated blood sampling (Accusampler) on serum corticosterone and faecal immunoreactive corticosterone metabolites and immunoglobulin A in male rats. J. Endocrinol. 180(1), 145-154.

Santhi, V.S., Salame, L., Dvash, L., Muklada, H., Azaizeh, H., Mreny, R., Awwad, S., Markovics, A., Landau, S.Y. \& Glazer, I., 2017. Ethanolic extracts of Inula viscosa, Salix alba and Quercus calliprinos negatively affect the development of the entomopathogenic nematode Heterorhabditis bacteriophora - A model to compare gastrointestinal nematodes developmental effect. J. Invertebr. Pathol. 145, 39-44. DOI org/10.1016/j.jip.2017.03.005

Siswanto, H., Hau, J., Carlsson, H.E., Goldkuhl, R. \& Abelson, K.S., 2008. Corticosterone concentrations in blood and excretion in faeces after ACTH administration in male Sprague-Dawley rats. In Vivo 22(4), 435-440.

Touma, C. \& Palme, R., 2005. Measuring faecal glucocorticoid metabolites in mammals and birds: The importance of validation. Ann. N. Y. Acad. Sci. 1046(1), 54-74. DOI 10.1196/annals.1343.006

Tuli, J.S., Smith, J.A. \& Morton, D.B., 1995. Stress measurements in mice after transportation. Lab. Anim. 29(2), 132138. DOI org/10.1258/002367795780740249

Von der Ohe, C.G. \& Servheen, C., 2002. Measuring stress in mammals using faecal glucocorticoids: opportunities and challenges. Wildl. Soc. Bull. 1215-1225.

Weary, D.M., Niel, L., Flower, F.C. \& Fraser, D., 2006. Identifying and preventing pain in animals. Appl. Anim. Behav. Sci. 100(1-2), 64-76. DOI org/10.1016/j.applanim.2006.04.013

Zeid, M., Echenique, V., Díaz, M., Pessino, S. \& Sorrells, M.E., 2011. Eragrostis. In: Wild crop relatives: Genomic and breeding resources. Springer, Berlin, Germany. 